\title{
The Value of Orff's Music Teaching Method in College Music Teaching
}

Yang Zhang*

H.S. Skovoroda Kharkiv National Pedagogical University, Kharkov 61002, Ukraine. E-mail: 364318864@qq.com

Abstract: As an innovative music teaching method, under the background of educational reform, Orff's music teaching method has increasingly attracted the attention and attention of university teachers. By applying the Orff teaching method in university music teaching, it can not only effectively promote the improvement of teaching quality, but also promote students to develop deep music exchanges and effectively cultivate students' musical literacy and innovative thinking.

Keywords: Orff Music Teaching Method; College Music Teaching; Value; Strategy

The Orff music teaching method is an innovative music teaching method founded by the famous German composer and musician Karl Orff ${ }^{[1]}$. The Orff music teaching method mainly has the following two characteristics: first, it emphasizes that music education has "original nature", and requires educators to pay attention to promoting the return of music education to its authenticity, that is, to return to life in the process of developing music education. To complete the music expression, it is necessary to achieve the organic combination of music and movement, dance and other performance elements in this process, so as to better complete the emotional penetration and let the students truly understand the emotions contained in the music; second, it emphasizes the development concept of "people-oriented", attaches importance to students as the basic starting point and final destination of music education, focuses on enhancing students' enthusiasm for music learning participation, and emphasizes on the effective cultivation of students' innovative practical ability through music teaching and enhance students' creativity.

Orff's music teaching method is highly operable. By applying it to university music teaching practice, teachers can effectively enhance the effectiveness of music teaching and promote students' deep music communication at the spiritual level. And in this process, there is emotional resonance and sublimation to achieve the improvement of personal character ${ }^{[2]}$. For this reason, university music teachers must construct a comprehensive understanding of Orff's music teaching method, and deeply understand the important value of applying Orff's music teaching method in university music teaching. It is important to master specific strategies for effectively applying the Orff music teaching method, and strive to build a new music teaching model with the help of the Orff music teaching method, so as to promote students' music literacy, music appreciation ability, and music innovation practice ability to be comprehensively improved, then earnestly achieve various music teaching goals.

\section{The important value of applying orff's music teaching method in college music teaching}

Copyright (C) 2020 Yang Zhang

doi: 10.18282/1-e.v9i1.893

This is an open-access article distributed under the terms of the Creative Commons Attribution Non-Commercial License

(http://creativecommons.org/licenses/by-nc/4.0/), which permits unrestricted non-commercial use, distribution, and reproduction in any medium,

provided the original work is properly cited. 


\subsection{Conducive to play the main role of students in music learning}

Under the traditional university music teaching model, teachers are the absolute leaders of teaching, and students are in a very passive position, often only participating in music learning through mechanized methods such as listening and simple imitation and it is difficult for them to form interest and passion for music learning from the heart ${ }^{[3]}$. Orff's music teaching method emphasizes the development concept of "people-oriented", attaches importance to mobilizing students' music learning subjectivity, and encourages students to actively engage in music practice and exploration.Therefore, under this teaching method, teachers must inevitably break through the limitations of the traditional teaching model, pay attention to in-depth optimization of the teaching plan, and strive to enhance the students' sense of participation in music learning, so it is conducive to the students' main role in music learning.

\subsection{Conducive to enhancing the life atmosphere of college music teaching practice}

Orff's Music law emphasizes the return to the "original", and clearly states that music is not only for expressing melody, but also for embracing its original life in a deep level ${ }^{[4]}$. Therefore, the application of Orff's music method in university music teaching is conducive to enhancing the life atmosphere of university music teaching practice, and prompting teachers to introduce daily music teaching materials and teaching content into specific music teaching, which can guide students to develop daily thinking and associations, effectively inspire the resonance of students' hearts and emotions, and promote students' in-depth understanding of music, grasp the essence of music, so as to truly devote yourself to music learning, and promote the improvement of music teaching quality ${ }^{[5]}$.

\subsection{Conducive to promoting students to develop innovative music practice activities}

The Orff music teaching method has a high degree of practical characteristics, emphasizing students' participation in music learning and the promotion of diverse music practice activities such as music appreciation, music performance and music creation in the teaching process. Therefore, it is conducive to promoting students to develop music innovation and creation. Since the teaching methods used in Orff's music teaching methods are relatively simple everyday instruments, students are more relaxed in the process of learning and mastering, which is conducive to further improving students' self-confidence and sense of accomplishment in music learning, and prompting them to actively participate in music practice activities.

\section{The specific strategies of applying Orff's music teaching method in college music teaching}

\subsection{Improve students' music perception}

Improving students' perception of music is not only an important teaching goal of university music teaching, but also a basic work that must be done to effectively apply Orff's music teaching method ${ }^{[6]}$. If the students do not have a qualified music perception ability, then they will be difficult to meet the requirements of Orff's music teaching method in the process of developing music performance practice, and it is difficult to carry out corresponding instrument performance activities. At the same time, it is difficult to form a deep musical interpretation in the practice of music performance. For this reason, university music teachers should effectively enhance students' music perception ability by organizing students to appreciate music and introducing things that students often contact in daily life in the process of music teaching. Meanwhile, it can also motivate students to use auditory senses to perceive and resonate with music, in the process of forming a deeper understanding and perception of music. For example, teachers can introduce the sounds of water and birdsong in the natural world into the teaching process, and use these natural sound sources to effectively create a teaching atmosphere and encourage students to listen to natural music, to achieve a "quiet" state of mind and gain the ability to perceive music.

\subsection{Combine the essence of national spirit and culture}

There is a close connection between music and life. Because of this, music conveys not simple melodies and 
musical notes, but contains ideas and emotions of a certain spiritual and cultural level. Only a deep understanding and grasp of music from the level of spiritual culture can be regarded as a complete understanding of musical works ${ }^{[7]}$. Orff's music teaching method emphasizes the "original nature" of music and attaches importance to returning music to life. Under this requirement, more attention needs to be paid to combining the national spirit and cultural essence, introducing national songs and other national music works into teaching practice, and better optimizing and perfecting the music perception, music performance and music creation practice. Then fully implement the concepts and requirements of Orff's music teaching method. For example, teachers can introduce classical folk music works performed by folk instruments such as erhu and pipa into teaching practice, let students use percussion instruments to restore folk music works, and form a deep understanding of the relationship between music and life, on the other hand, let students understand the characteristics of different national music, the influence of national living environment and historical changes on their musical styles, so as to further improve the students' ability to understand and interpret music.

\subsection{Carry out various music practice activities}

The core and key to the effective application of Orff's music teaching method is to organize students to carry out various musical practice activities, and to encourage students to start creative innovation at the music level during the participation process ${ }^{[8]}$. To this end, university music teachers should form an all-round understanding of the characteristics of students, integrate relevant information, and form specific activity plans to effectively mobilize the subjective initiative of students and allow students to perceive music and understand life in this process. In this regard, university music teachers should introduce special Orff instruments into the music teaching practice, and teach their performance methods to students, help students to master the essentials of performance, and let students use Orff instruments to develop music performance and music creation practice. In this process, a deeper understanding of the "original nature" of music is formed. At the same time, teachers should attach importance to mobilizing students to communicate and share the feelings of playing Orff instruments, and encourage them to resonate emotionally at the spiritual level, in order to create a good teaching atmosphere and promote students to share thinking,further improve their music perception ability and music interpretation ability.

\subsection{Improve music course evaluation mechanism}

Under the guidance of the "people-oriented" concept of student-oriented education, in order to further enhance the practical effectiveness of Orff's music teaching method. University music teachers should pay attention to the improvement of the music course teaching assessment and evaluation mechanism, and strive to break through the traditional method of giving students a single evaluation of the final test, and establish a complete evaluation standard. It is important to incorporate the learning enthusiasm shown by students in music classrooms, the achievements of students' musical practice and the improvement of students' musical literacy through music learning into the evaluation system, and strive to give students a more diverse and comprehensive evaluation. In addition, it is also necessary to promote students to understand their music learning situation, and promote them to optimize their music learning behavior and habits. In this process, teachers should also pay attention to organize students to carry out self-evaluation and mutual evaluation, so that they form a habit of continuous reflection and summary in the music learning process. In addition, teachers should also provide students with the opportunity to evaluate teachers, in this way to understand students' suggestions for music teaching, adopt reasonable parts of them, and promote the optimization and perfection of teaching programs.

\section{Conclusion}

All in all, based on the important role of applying Orff's music teaching method in enhancing the initiative of students' music learning subjects, enriching the atmosphere of university music teaching life, and promoting students' participation in innovative music practice activities. At university, music teachers should increase the emphasis on this 
music teaching method, combine its originality and "people-oriented" development concept, improve and optimize the music teaching plan, through implementation to enhance students' music perception ability, penetrate the essence of national spirit and culture and it is important to carry out a series of strategies such as rich music practice activities and construct a sound music course evaluation mechanism to maximize the positive role of Orff's music teaching method in university music teaching and construct an efficient music teaching model,and promote students' core literacy in music to achieve all-round development.

\section{References}

1. Wang C. Exploration of the value of integrating the music teaching method of Orff in college music classroom (in Chinese). Chinese and Foreign Entrepreneurs 2019; 634(8): 172.

2. Ye X. Practice of Orff's music teaching method in piano music teaching in colleges and universities (in Chinese). Journal of Jilin Education College (Early) 2018; (7): 94-96. doi: 10.16083/j.cnki.1671-1580.2018.7.024.

3. $\mathrm{Xu} \mathrm{J}$. A study on the strategies of integrating Orff's music teaching method in college music teaching (in Chinese). Northern Music 2018; 38(24): 196. doi: 10.3969/j.issn.1002-767X.2018.24.114.

4. Yan X. The importance of Orff's music teaching method in college music teaching (in Chinese). China Nationalities Expo 2019; (10): 57-58+66. doi: 10.3969/j.issn.1007-4198.2019.10.036.

5. Liu G. Application of Orff's music teaching method in college music education (in Chinese). The Sound of the Yellow River 2018; (1): 88.

6. Chen T. Research on the application of Orff's music teaching method in college music teaching (in Chinese). Voice of the Yellow River 2018; (4): 86.

7. Liu J. Analysis of the application of Orff's music teaching method in college music classroom teaching (in Chinese). Sound of the Yellow River 2016; (12): 26.

8. Qi W, Wang Y. Application of Orff's music teaching method in college music teaching (in Chinese). Voice of the Yellow River 2016; (6): 64-65. 